\title{
Kernos
}

Revue internationale et pluridisciplinaire de religion grecque antique

$27 \mid 2014$

Varia

\section{The priestess of Athena Nike}

A new reading of $I G I^{3} 35$ and 36

Josine Blok

\section{Q OpenEdition}

1 Journals

\section{Electronic version}

URL: http://journals.openedition.org/kernos/2274

DOI: $10.4000 /$ kernos.2274

ISSN: 2034-7871

\section{Publisher}

Centre international d'étude de la religion grecque antique

\section{Printed version}

Date of publication: 1 November 2014

Number of pages: $99-126$

ISBN: 978-2-87562-055-2

ISSN: 0776-3824

\section{Electronic reference}

Josine Blok, «The priestess of Athena Nike », Kernos [Online], 27 | 2014, Online since 01 October 2016, connection on 19 April 2019. URL : http://journals.openedition.org/kernos/2274 ; DOI : 10.4000/

kernos. 2274

This text was automatically generated on 19 April 2019

Kernos 


\section{The priestess of Athena Nike}

A new reading of IG $\mathrm{I}^{3} 35$ and $36^{*}$

Josine Blok

1 The decree inaugurating the priesthood of Athena Nike (IG I ${ }^{3}$ 35; Fig. 1) signalled a new stage in the development of democratic Athens. ${ }^{1}$ On the proposal of a man whose name is now almost entirely lost, IG $\mathrm{I}^{3} 35$ decides to select a woman by lot to be the first priestess of Athena Nike, to add doors to the sanctuary made by Kallikrates, to give the priestess 50 drachmas and choice parts of the sacrifices made on behalf of the dêmos, and that Kallikrates build a temple for Athena Nike and a stone altar. The new priestess was to be allotted from among all Athenian women, a decision giving all citizens, in this case female citizens, access to prominent cultic roles in the polis. A rider by a certain Hestiaios appoints a committee from the boule to oversee the contracts. 


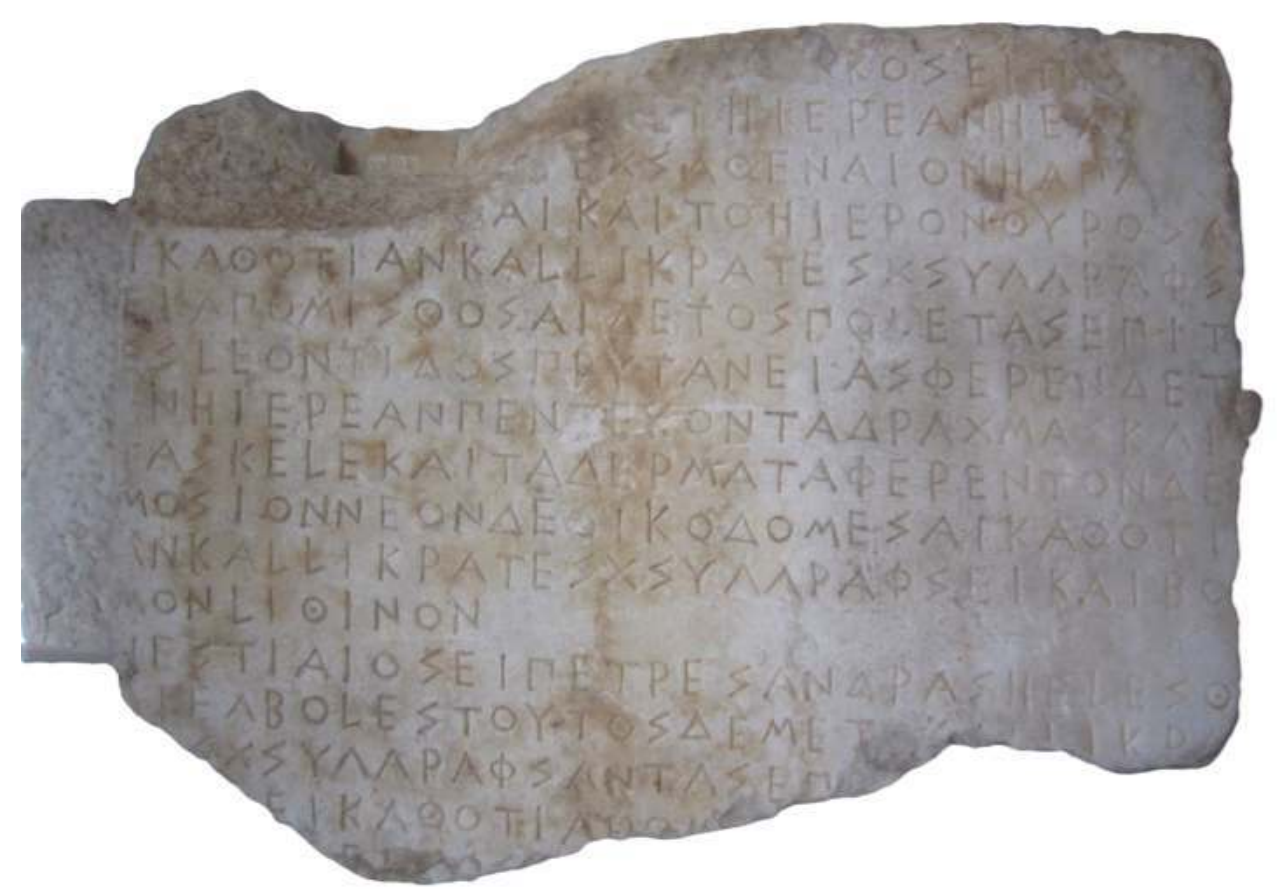

Figure 1

Photo: Josine Blok, by courtesy of the New Akropolis Museum

Unfortunately, the stone on which the decree was inscribed is much damaged, both on the top and at the bottom, where a part was broken off. In its present state, the text of the decree lacks any clue as to the moment of its enactment. Until some years ago, the conventional date of IG $\mathrm{I}^{3} 35$ was ca. 448, due to the 'three-bar sigma' letterform allegedly not used after 446, but since this criterion is now abandoned, no satisfactory date for this decree is established. ${ }^{2}$ Circumstantial evidence suggests a date post 448 , when the Akropolis building program was conceived and to which the embellishment of the cult of Athena Nike and the construction of her temple must belong. A certain ante quem is a decree (IG I ${ }^{3} 36$; Fig. 2) inscribed on the back with specifications about the priestess' payment, which refers explicitly to the earlier decision. This decree has a prescript though one without an archon and is conventionally dated to 424/3. 


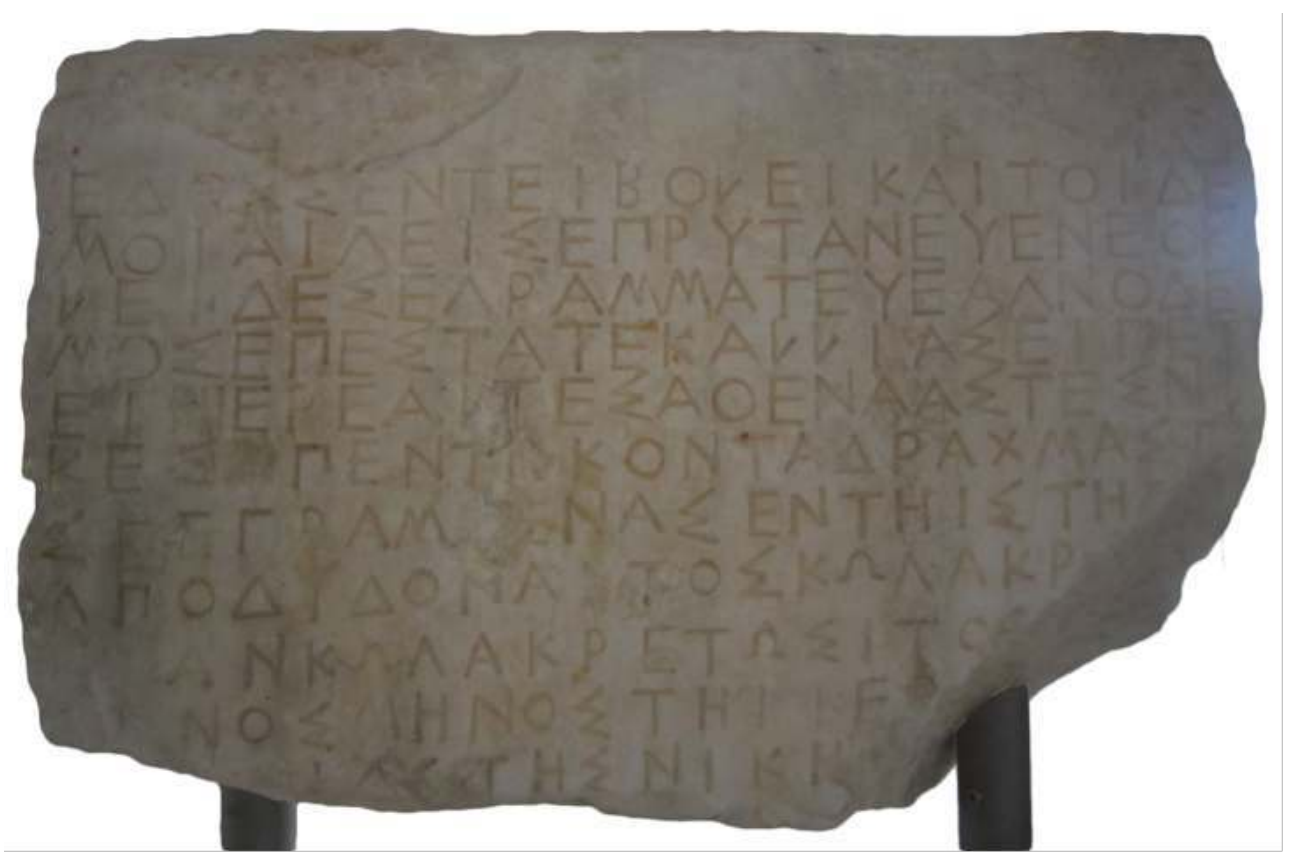

Figure 2

Photo: Josine Blok, by courtesy of the New Akropolis Museum

Both decrees have been discussed extensively and republished several times since their editio princeps in 1897, the present authoritative editions being IG $\mathrm{I}^{3} 35$ and 36 and ML 44 and 71. To honour the memory of Christiane Sourvinou-Inwood, I should like to revisit both decrees with two ways of reading: a microscopic reading of the stone and a reading of the cult in the wider framework of polis religion. ${ }^{3}$

\section{The texts of $\left.I G\right|^{3} 35$ and 36}

4 Let us first look at the texts (see also Appendix). The top line of decree IG I ${ }^{3} 35$ is much

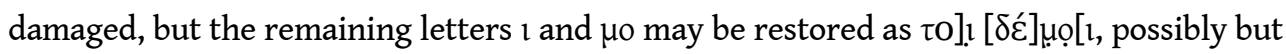
not necessarily part of an enactment clause. ${ }^{4} \mathrm{~A}$ prescript with reference to archon, prytanis or grammateus is lacking, and so is a statement about setting-up the stele. ${ }^{5}{ }^{G} \mathrm{I}^{3} 36$ stipulates that the kolakretai who will be in office in the month $\mathrm{Th}[. .$.$] are to pay the$ priestess of Athena Nike the fifty drachmas decided in the first decree. In 1. 9, the $\Theta$ seen by $\mathrm{H}$. von Prott and now hardly visible is confirmed by one squeeze in Texas, and the number of letters is consistent with $\Theta \alpha \rho \gamma \eta \lambda$ i $\tilde{\omega}$ voc. Thargelion may therefore be considered as good as secure. The two decrees raise many much-debated questions, notably on the date of 35 in connection with the construction of the Propylaea, the Nike temple and other buildings by Kallikrates, the question on whether the priesthood was annual or for life, and on the office of the first priestess, Myrrhine. ${ }^{6}$

5 The stone on which both decrees are inscribed has an extraordinary shape (Fig. 3 and 4). The top of the stone has a scarf-joint cutting at an oblique angle with anathyrosis and dowel holes. W.B. Dinsmoor and A.B. West, who until a few years ago seem to have been the last scholars to have studied the stone itself, calculated from the angle of the slope that the stone must have been joined to another one in such a way that our extant stone 
held the first lines of the decree. ${ }^{7}$ On this reconstruction, the prescript was very likely inscribed on the upper stone. The size of this top stone can only be guessed at, but it cannot have been very large; a scarf-joint makes a smooth connection, but in vertical position the construction did not allow the lower stone to carry a heavy load. No parallel of such a construction is known. B.D. Meritt accepted Dinsmoor's conclusions and recently Stephen Lambert confirmed them from autopsy. ${ }^{8}$ Given this reconstruction, Meritt observed that considering the thinness of the stone where the first line of 35 was inscribed (now reduced to hardly half its original size due to damages over time), the stones must have been joined before our present decree 35 was cut. The text would have run continuously from top to lower stone, with the joint precisely in-between lines.

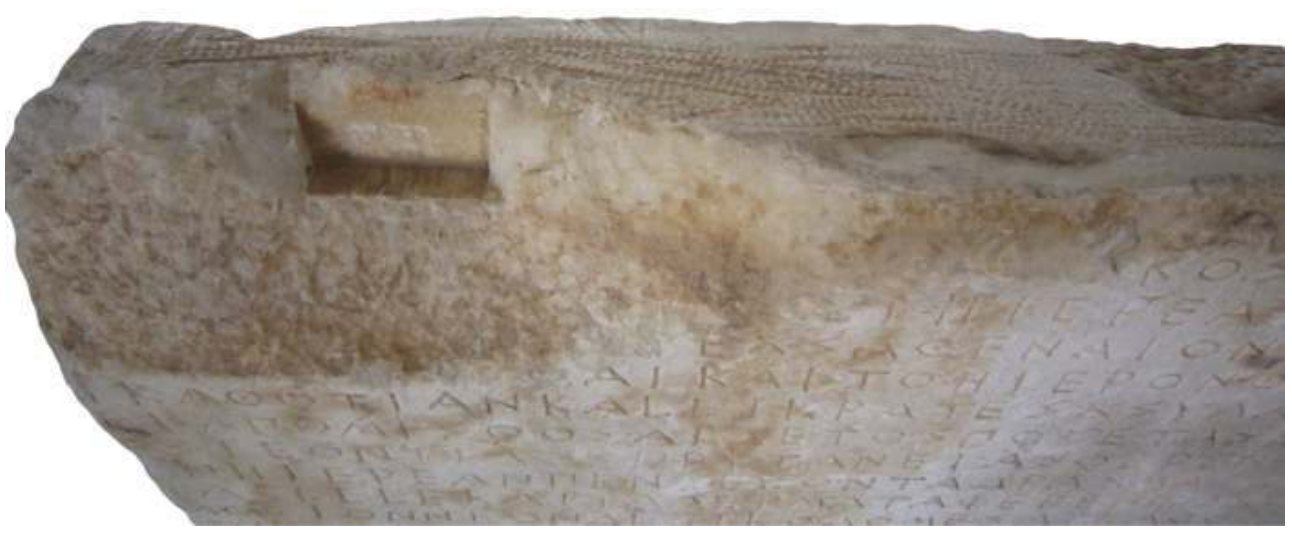

Figure 3

Photo: Josine Blok, by courtesy of the New Akropolis Museum

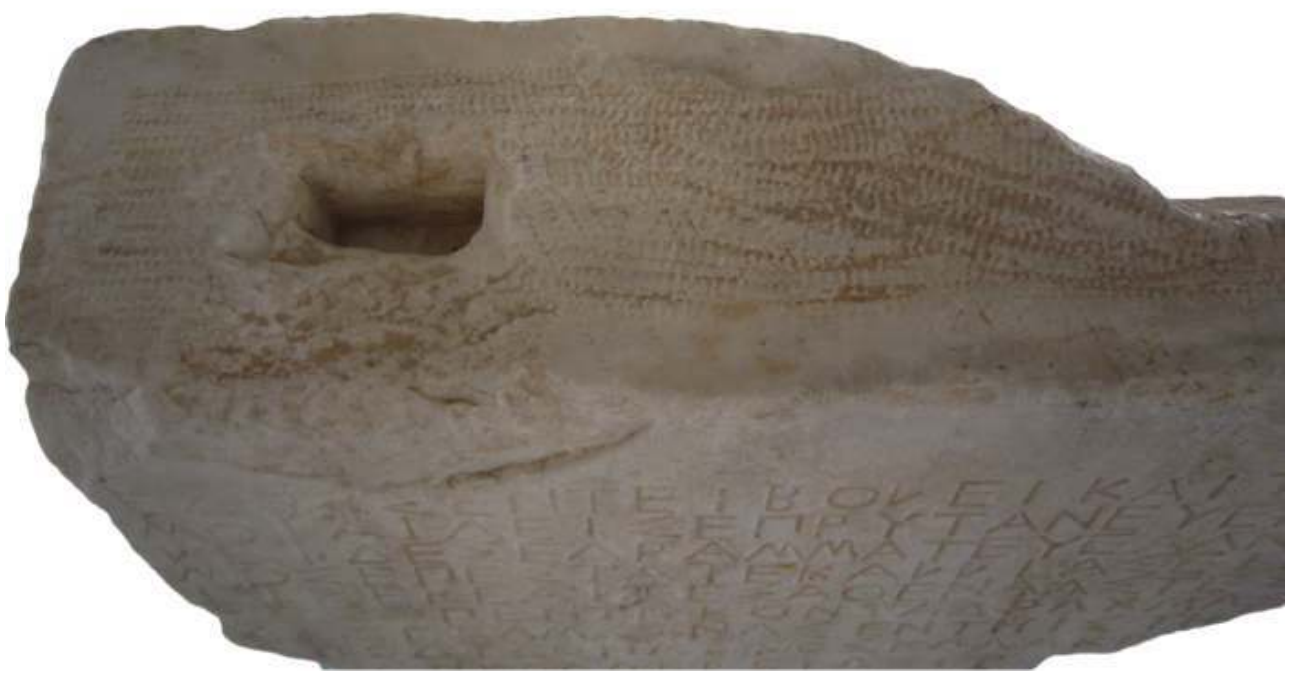

Figure 4

Photo: Josine Blok, by courtesy of the New Akropolis Museum

6 From all of this, Meritt inferred in his first publication on the decree (1941) that the top stone held the main decree with the prescript and that the proposal beginning on 1.2 of 35 was a rider. The fact that the rider by Hestiaios begins on a separate line, whereas the 
first proposal did not, he ascribed to irregular punctuation. ${ }^{9}$ But what decree might the top stone have held? In 1963, Meritt and H.T. Wade-Gery stated that decree 35 was

an amendment, not part of the decree proper. Whatever the decree was about, it must have been something of such importance that the reorganisation of the cult of Athena Nike and the construction of a new temple and altar could be added as an appendage to some larger plan [...]. Its main subject-matter was almost surely the architectural organisation of the western approach to the Akropolis. Nothing less than this, which included the planning for and the authorisation of the Propylaea, will have been of sufficient moment to carry the temple of Athena Nike merely as a rider. ${ }^{10}$

Later, however, Meritt changed his mind, now identifying the first proposal of 35 not as a

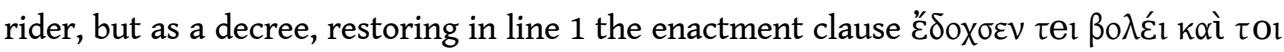
$\delta \varepsilon ́$ por. In IG, Meritt and Malcolm F. McGregor published the decree in this form, adding

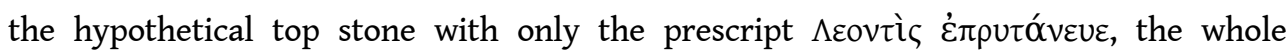
reconstructed 35 now consisting of a single decree. R. Meiggs and D. Lewis, however, doubted Meritt's solution and in their edition they did not include any hypothetical text of the top stone. ${ }^{11}$ Neither IG nor ML offers an explanation for the extraordinary construction of the two stones joined by dowels.

Before turning to other aspects of the decrees, I should like to observe that: (a) on all more or less contemporary decrees, riders are introduced by the clause ( $\tau \grave{\alpha} \mu \grave{v} v$ ó $\lambda \lambda \alpha$ ) $\kappa \alpha \theta \alpha \dot{\alpha} \pi \varepsilon \rho . .$. following either the advice of the boulê or a proposal by somebody else introducing a rider, and some are separated from the previous text by a vacat. This fixed clause is lacking in the first proposal of 35. (b) Hestiaios' proposal also lacks this fixed clause, but instead is indicated to be a rider by beginning on a new line, after a vacat; again, such a mark is lacking in the first proposal. ${ }^{12}$ On this evidence, it seems highly unlikely that the first proposal of 35 is a rider. Merritt's restoration of line 1 into the enactment clause is not absolutely certain, but in my view it is the most plausible. If we accept this, the text of 35 is a decree beginning with an enactment clause, followed by the rider of Hestiaios.

In a new attempt to make sense of the Athena Nike decrees, I first ask a different type of question. What was the new priesthood for?

\section{The cult of Athena Nike}

10 The cult of Athena Nike had existed since at least the sixth century, as attested by a limestone altar dedicated to her, and a sanctuary with a temenos wall, a cult statue and a naiskos. ${ }^{13}$ Situated on the bastion on the promontory of the Akropolis, Athena Nike's was a polis-cult in every sense in which Sara Aleshire and Stephen Lambert define it, that is to say, paid, overseen, fostered or supported by the polis in some way. ${ }^{14}$ Under the classical sanctuary, a repository consisting of two poros blocks, possibly the base of the archaic cult statue, was found, which held a mixture of sherds, bones and shattered terracotta figurines. Comparable assemblages suggest that these gifts belonged to the original dedication of the sanctuary and altar, and were incorporated in the foundations of the new sanctuary. ${ }^{15}$

In the sixth and fifth centuries, Athena received hundreds of inscribed dedications from private worshippers on the Akropolis, but only two such gifts carry an epithet: one for Athena Hygieia, another for Athena Poliouchos. ${ }^{16}$ Did 'Athena' without epithet include 
Athena Nike? We cannot rule this out, but it is not the most plausible option, considering that Athena Nike enjoyed a cult as a goddess in her own right with her typical epithet. ${ }^{17}$ If this is correct, the only extant inscribed dedication to Athena Nike is the altar and there is no unambiguous evidence of private worship, for instance dedications made after athletic competitions. The absence of such evidence confirms the prevalent view that in this cult Athena Nike was not a goddess of victory in (athletic) competition, but the divinity promoting victory in war. ${ }^{18}$

Whereas the special cult for Athena Nike thus clearly existed, it had no special priestess; IG I ${ }^{3} 35$ installed a priestess for Nike for the first time. ${ }^{19}$ No extant evidence tells us who took care of this cult and supervised the sanctuary before the new priestess entered her office. Some scholars suggest that the genos Eteoboutadai, in particular the priestess of Athena Polias, had been in charge of the cult of Athena Nike, considering the genos' conspicuous role in the cults on the Akropolis..$^{20}$ If so, the authority of the Eteoboutad priestess would have included performance of cult actions such as sacrifice by others. The phenomenon of a cult being gradually elaborated with new features, such as a priest(ess) of its own, is not unique in Athenian religion..$^{21}$ Athene Nike also received a substantial income, albeit from unknown sources, since by the 430s she owned an impressive treasury from which the polis borrowed heavily. ${ }^{22}$ Assuming that her money was stored, as was conventional, in her sanctuary, which before its embellishment consisted merely of a temenos wall, it would naturally have been prudent to add doors that could be closed, such as ordered in decree IG $\mathrm{I}^{3} 35,1$. 5. IG $\mathrm{I}^{3} 45$, again of unknown date, orders Kallikrates to plan and build quickly some construction on the Akropolis to keep runaway slaves and vagabonds out, and appoints three archers as guards from the phyle who holds the prytany. Apparently, there were reasons to worry about the well-stocked treasuries on the Akropolis.

13 Archaeological evidence provides some idea of the major hiera for Athena Nike. Before its refurbishment in the Periklean program, the sanctuary held a rectangular limestone altar dating to shortly before the middle of the fifth century; it must have replaced the archaic bomos, but decree 35 wanted it to be replaced in its turn by a stone one..$^{23}$ Judging by the prominence of these altars, it seems that public sacrifice was a major element of Nike's cult. In the 'Law and decree on the 'Little' Panathenaea' of ca. 335, the hieropoioi are to buy a large number of cattle with the monies newly raised from the Nea and to select one particularly beautiful cow for sacrifice on the altar of Nike. ${ }^{24}$ What precisely was traditional and what was new in the arrangements of this law is not thoroughly clear, but the sacrifices for which the law made the hieropoioi responsible seem to be a new provision owing to the new funds. ${ }^{25}$ What happened before, who performed sacrifices for Nike and when did they take place? Considering that since its archaic origins Athena Nike's role was to foster victory in battle, we might think of the polemarchos as a plausible candidate to have been in charge of earlier sacrifices, but there is no certainty on the matter. ${ }^{26}$ The only evidence so far are the reliefs on the parapet of the new sanctuary dating to ca. 415-10, showing a procession of Nikai leading male bovines to be sacrificed; male animals were normally not sacrificed to goddesses, so these must have been cattle sacrificed under Nike's supervision before battle, as M. Jameson convincingly argued. ${ }^{27}$ I return to these sacrifices below.

14 War booty was occasionally dedicated on the Akropolis, the first extant example being the spoils of the war from the Boeotians and Chalcidians in 506 (IG $\mathrm{I}^{3}$ 501A), but all of these were dedicated to Pallas Athena. To go by the extant epigraphical and 
archaeological evidence, Athena Nike seems to have received her first spoils in her new sanctuary, namely a bronze statue dedicated from spoils of campaigns in 427 to 425 and shields captured at Pylos in 425 and hung on the bastion the following year. ${ }^{28}$ In Peter Schultz' words, the Nike temple was now a 'permanent, prominent, Athenian war votive'. ${ }^{29}$ These dedications seem to be further examples of a policy to grant special honours to Athena Nike, that decree 35 inaugurated or to which it contributed. What was the priestess to do in all of this?

\section{The office of the priestess of Athena Nike}

Our evidence on her office in the fifth century consists primarily of the texts of $I G \mathrm{I}^{3} 35$ and 36 as well as the Myrrhine epigram (IG I ${ }^{3} 1330$ ) that confirms the duties of the priestess to take care of the sanctuary and its statue, and, most importantly, confirms her selection by lot (1. 6). In the debate on the decrees and the priesthood, however, a few elements seem to have played a somewhat misleading role.

Firstly, the temple. IG $\mathrm{I}^{3} 35$ inaugurates both the plan for a temple and the priesthood, but the date of the actual construction of the Nike temple is as heavily debated as that of the decree that commissioned it. Scholars agree that for the construction of the Propylaea the bastion of the promontory was raised to be on the same level as the southwest wing, while the whole was designed to match the overall plans of the Akropolis. ${ }^{30}$ Supporting the connection between this construction and IG $\mathrm{I}^{3} 35$, there is one architectural fact: the sheathing of the bastion and the foundations of the Nike temple were made at the same time. ${ }^{31}$ If this means that both were conceived in one plan from the beginning, this plan was in all probability IG $\mathrm{I}^{3} 35$ and the decree must then predate the construction of the Propylaea. But if we date IG $\mathrm{I}^{3} 35$ to the early-440s, close to the first stage of the Periklean building program, or to the early-430s, close to the beginning of the construction of the Propylaea in 437/6, how is the gap in time between the decree 35 and 424/3, the date of the decree 36 about the priestess' payment, to be explained? ${ }^{32}$

Moreover, how soon did the actual building of the temple follow on the decree?Since the beginning of the construction of the Propylaea, the design of the southwest wing was revised several times. For the date of the construction of the Nike temple, we must rely on relative chronology of architectural elements compared with other buildings of these years. Margaret Miles argued that the Nike temple was built somewhat later than the temple for Artemis Agrotera on the Ilissos, by the same Kallikrates who was commissioned to build the Nike temple. Miles dated the Ilissos-temple to ca. 435-30 and the beginning of the Nike-temple shortly before 434 , because small chips of marble, that she supposed were cut off when the Propylaea were being finished, were found under its foundations..$^{33} \mathrm{~A}$ terminus ante quem for the Nike-temple are its friezes, whose style is dated to ca. $420-18$ on comparison with other relief sculpture for which absolute dates are available. ${ }^{34}$ I. Mark, although contesting that the marble chips derived from the Propylaea, concludes for the Nike-temple that '[a]rchitectural criteria point to a date at earliest toward the close of the Propylaea project in the late 430's, at latest in the early years of the Erechtheion project, begun ca. $420{ }^{35} \mathrm{~J}$. Hurwit sees two possibilities for the construction program: either the raising of the bastion belonged to the first stage of the Propylaea terminated in 432, or the southwest wing of the Propylaea as it stands now belonged to the raising of the bastion and the building of the Nike temple in the $420 \mathrm{~s}^{36}$ 
In this debate, architectural elements provide a relative chronology, which is asked to cohere with (the majority undated) inscriptions in order to create a reasonable chronological order of events. While such reasoning has weaknesses of its own, in this case there is also an acute problem. The contention that the first stage of the Propylaea was terminated and the work on the Nike temple began in the late 430s, depends on the conventional reconstruction and dating of the much-disputed Kallias-decrees (IG I ${ }^{3} 52 \mathrm{~A}$ and B; ML $58 \mathrm{~A}$ and B), two decrees dealing with monies of Athena inscribed on either side of a stele. 'Kallias' B, which is much more damaged than Kallias A, concerns work on the Pro[pylaea] and poses a limit of 10,000 dr. to be drawn from Athena's reserve without authorisation. H.T. Wade-Gery restored its missing prescript as the prescript of decree A with its proposer Kallias, making it a decision of the same session of the assembly. Since B belonged to a Panathenaeic year, so must A if it held the same prescript. The first phrase in B (1. 3-4) on the Pro[pylaea] was restored with 'to complete'. Other scholars, among whom M. Cavanaugh, did not think that the reference to the Panathenaea in B compellingly dated both decrees to a Panathenaeic year and advanced independent arguments for a date in 432 . In any case, both decrees seemed to imply that due to financial constraints before the impeding war the work on the Propylaea was finished, or rather interrupted, in or shortly after 434, as we saw in the arguments of Miles (434) and Hurwitt (432). ${ }^{37}$ This reading of the Kallias-decrees, which filled the gaps in chronological data in the epigraphical and archaeological evidence, evolved into a near consensus among historians and archaeologists in the 1970s and 1980s..$^{38}$ Against this reading, however, L. Kallet-Marx and L.J. Samons convincingly argue for quite different dates, $431 / 0$ or 432 for Kallias A and 422/1 for 'Kallias' B, as well as for quite different contents of $\mathrm{B}$, without the alleged termination of the first stage of the Propylaea. ${ }^{39}$ Given that the epigraphical support for this stage in the late 430s has now evaporated, and with it a date for the beginning of the Nike-temple, we now only have a terminus ante quem for the latter, the late 420 s.

19 Secondly, there is the priestess' payment, that IG $\mathrm{I}^{3} 36$ was decreed to settle. The date of the decree is probably $424 / \underline{3}$, since most scholars take the secretary Neokleides to be the same as the Neokleides who drafted $I G I^{3} 75$, a treaty with Halieis that was very likely concluded in $424 / \underline{3}^{40}$ This date also fits well with the time when the temple was nearly finished and hence some scholars assume that the completion of the temple triggered the regulation of the payment. ${ }^{41}$ For instance, H.B. Mattingly, who had always objected to a wide gap of time between decrees 35 and 36, at first had defended a date of ca. 430 for decree 35 , but later favoured an even closer connection between them. In his view, decree 35 with the decision to create the priesthood and to build the temple, and IG $\mathrm{I}^{3} 64 \mathrm{a}-\mathrm{b}$ voting for the bronze statue of Athena Nike, both belonged to 425 . Hardly a year later, her payment was neatly arranged and further decisions about the temple were taken in decree $36 .{ }^{42}$ Although Mattingly's solution would solve some of the riddles arising from a (much) earlier date of decree 35, it is not really convincing, because he does not take the architectural data concerning the temple sufficiently into account.

Whether or not a substantial interlude between 35 and 36 is deemed plausible, in this debate the temple features as the indispensable backdrop for the priestess' office, as if she somehow 'carried out her office' there. ${ }^{43}$ But that is not necessarily the case. The office of a priest or priestess was to perform certain cultic actions, notably sacrifice, for which s/he did not need a temple but only an altar. Decree IG I 35 takes the initiative for both the priestess and the temple, but the temple and the priestess did not depend on one 
another. Put differently, there is no intrinsic need to immediately connect the actual construction of the temple to epigraphical data on the priestess or vice versa.

What was decree IG $\mathrm{I}^{3} 36$ about? It orders the 50 drachmas agreed in the former decree to be paid in Thargelion by the kolakretai. Some scholars take this regulation to mark the priestess' first payment on entering her office, others think it entailed a change, for instance in the source of the money (henceforth from the treasury held by the kolakretai), while the priestess had been in office since decree 35 . Either way, the payment is usually called a 'salary', as if in Thargelion she were paid for an office on an annual basis. ${ }^{44}$ But this idea of a 'salary' implies anachronistic notions of state service and is therefore an inadequate 'filter' - to use Christiane Sourvinou's terminology - through which to perceive the priesthood.

Salaries in the sense of payment for one's time, let alone for a stretch of time as long as a year, were unknown in classical Athens. Normally, people were paid for the services or goods they provided; selling one's labour for a prolonged time was a sign of dependency. ${ }^{45}$ Polis officials were appointed for a year, but any misthos they received was a fee per session or service. Priests and priestesses received payment in money and / or in kind for their cultic actions, called gera(s) and in Athens also hierôsyna or apometra. ${ }^{46}$ For sacrifice, the backleg of the sacrificial animal as mentioned in decree 35 was a conventional piece of honour for priests, and so were hides as a perquisite. ${ }^{47}$ At Athens, examples of payment in money are the $3 \mathrm{dr} .3 \mathrm{ob}$. per person to the Eumolpidai for initiation in the Eleusinian Mysteries and 16 drachmas for priests of the Ionian phyle Geleontes for sacrifices to Zeus Phratrios and Athena Phratria..$^{48}$ The highest fees extant in the polis calendar are 100 drachmas for the priestess of Demeter for a biennial sacrifice, and 30, 70 or 120 drachmas for the priestess of Athena Polias for a sacrifice in Metageitnion. ${ }^{49}$ On this evidence, the 50 drachmas for the priestess of Athena Nike must have been a fee for performing sacrifices on behalf of the dêmos, of which she also received her perquisite in kind. What sacrifices were these?

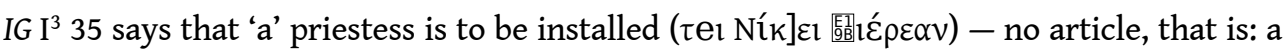

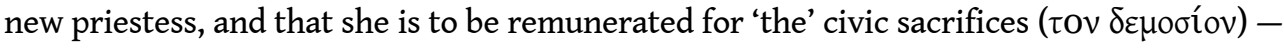

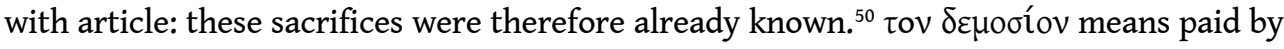
the dêmos and for the benefit of the dêmos, in other words, dêmotelês. ${ }^{51}$ Were these sacrifices the traditional sacrifices presumably performed since the mid-sixth century? That is not very likely. It would be against Athenian custom to take a sacrifice or any other cultic action away from the traditional performer to assign it to someone else. Rather, when the polis wanted to give new honours to a deity, a new cult or activity was established and a new person was assigned to perform it. ${ }^{52}$ In this particular case, giving a new priestess but no extra sacrifices would be a poor tribute to Athena Nike, whose cult was embellished in this scheme on a large scale. Finally, 50 drachmas is a substantial fee, for performing apparently sizeable sacrifices. In sum, it is more likely that these were new sacrifices and quite grand at that. The new altar measured almost $4 \mathrm{~m}$. across, which is ample space for a generous offering. ${ }^{53}$

On this close-reading of IG $\mathrm{I}^{3} 35$, I suggest that preceding this decree a decision was made to honour Athena Nike with special dêmotelês sacrifices; let us call this decision decree pre-35. Next, a priesthood was created to perform this new sacrifice, plus a new temple, plus a new altar; this is decree 35 . 


\section{Sacrifices for Athena Nike}

25 parallel is the sacrifice of 500 goats to Artemis Agrotera on her festival on $6^{\text {th }}$
Boedromion, celebrating the victory at Marathon. Tradition held that before the battle the Athenians made a vow to sacrifice a goat to Artemis Agrotera for every Persian killed at Marathon, but the dead were so numerous that the number was fixed on an annual offering of $500 .{ }^{54}$ Following a procession to the shrine of Artemis, this large sacrifice was still performed by the polemarchos in the days of the Athenaion Politeia, and it was the first public festival connected to the Persian wars instituted by the dêmos. ${ }^{55}$ More celebrations of the victories followed, the next major one being the Theseia, instituted when Kimon captured skyros and due to an oracle brought the hero's bones from the island to Athens in 476/5. Performance of the new sacrifices of this festival was assigned to the genos Phytalidai, who were anchored in the same deme as Kimon, and paid for by a special tax of five drachmas, probably levied on a group of prominent families. ${ }^{56}$ Special sacrifices for Athena Nike would fit very well in this series of civic sacrifices connected to the Persian wars, since they carried both a propitiating and a commemorative function. Paid for by the dêmos, the sacrifices would strengthen the charis between the dêmos and the goddess to the benefit of the dêmos.

If this hypothesis makes sense of the purpose of $I G \mathrm{I}^{3} 35$, the payment to the priestess still shows some irregularities compared to similar cult- and cost-regulations. Normally, the kind of sacrifice was fixed, by tradition or by decree, as was the moment when it was to take place (at least the festival month) and the perquisites following on the performance. Decree 35 only specifies the perquisites, decree 36 only the festival month when the fee is to be paid and by which body. ${ }^{57} \mathrm{~A}$ conjunction with a sacrificial event is lacking here, and therefore it seems that payment of the money took place separate from the sacrificial act. On the other hand, since the decree does not mention a specific arrangement for the meat and hides, apparently the priestess received those as normal, after the sacrifices. Taken together, this evidence suggests that the priestess performed civic sacrifices at more than one moment in the year and / or at unspecified moments. For all of these sacrifices she received payment in one month, Thargelion, and the meat and hides immediately after each sacrifice..$^{58}$ It is noteworthy that Thargelion is in the late Spring, when the war season began. ${ }^{59}$ The time of payment is set in a month in the festival calendar, not the bouleutic calendar, and this suggests a connection with a sacrificial calendar, rather than with the administrative schedule..$^{60}$ In the fifth century, there are no extant parallels for such a regulation of payment in a specific month by the kolakretai.

On all this evidence, I would tentatively conjecture that the priestess was to perform new sacrifices, perhaps before campaigns but especially after victorious battles. What kind of sacrifices these civic sacrifices for Athena Nike were is difficult to tell, but I would like to clarify their role in comparison to the cattle depicted on the parapet reliefs. I return here to Jameson's argument that the parapet reliefs depict the sphage, the cutting of the throat of sacrificial animals before battle, a sacrifice that did not or only rarely address a particular deity but mainly served as a means of divination and as a general propitiatory offering. ${ }^{61}$ Normally, armies sacrificed goats and rams, ${ }^{62}$ and fine male bovines such as depicted on the parapet were probably not sacrificed in reality for this purpose. Rather, 
the reliefs depict a splendid sacrifice of precious cattle supervised by Athena Nike in the presence of Athena, in a symbolic representation of which

the message is blunt, even brutal: Victory and Athena guarantee the success of the Athenian people, committed to battle. Nike, under Athena's eyes, ensures by the violent act of killing that the Athenians will win. ${ }^{63}$

I would argue that the civic sacrifices for Athena Nike belonged to same 'message' but were neither the sacrificial animals such as those depicted on the parapet, nor the goats or rams actually killed before battle in sphage. The male cattle were unsuited for Athena Nike, as mentioned before, and the sphage sacrifices were likewise not meant in particular for this goddess, who normally would receive a thank offering after the victory. Moreover, sphage sacrifices could hardly be considered 'civic' in the usual sense and they were made on a battlefield (far) away from Athens, a fact that made giving the hides to the priestess not impossible, but at least highly impractical. If my hypothesis is valid, the sacrifices to which decree 35 refers were meant for Athena Nike and to be offered in her sanctuary on the Akropolis on the altar there, in due course on the new stone altar.

Some tenuous evidence supports this hypothesis, notably the association of Athena Nike with Artemis Agrotera. As mentioned above, Kallikrates was commissioned to build new temples for both goddesses, in gratitude for their protection and the victories in the Persian wars. ${ }^{64}$ Besides this architectural connection, we find a tiny epigraphical trace on the sacrificial calendar of Athens recorded in 404-399, listing a sacrifice on $6^{\text {th }}$

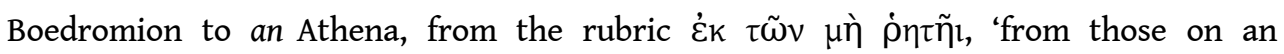
unspecified day'. ${ }^{65}$ The epithet of this Athena is not preserved; was she perhaps Athena Nike, with one of the sacrifices for her now fixed on the festival of Artemis Agrotera, 'Marathon' day?

\section{The making of $I G I^{3} 35$}

If this reconstruction makes sense, we are in a better position to explain the phrasing of decree 35 and perhaps also the extraordinary construction of the stone. Again, this explanation is entirely conjectural because parallels do not exist. First, decree pre-35 was enacted, inaugurating the civic sacrifices to Athena Nike in her sanctuary. A provision for the money to pay for these sacrifices was probably included. Next, the decision elaborating decree pre-35, now IG I ${ }^{3} 35$, was made. Above, I argued that the proposal by the unknown man in line 2 was most likely not a rider, but a decree, and that we might

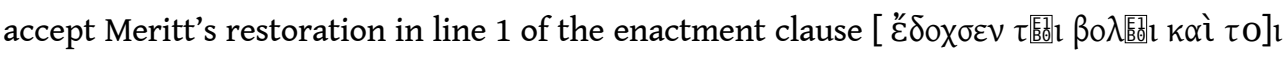

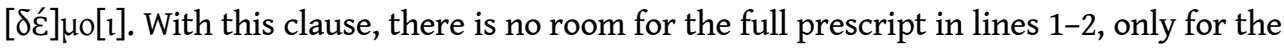
epistatês.

31 For such a drafting, the following hypothesis would provide an explanation. If decree 35 was enacted in the same prytany and with the same grammateus as pre-35, but on another day with a different epistatês, the prescript of pre-35 would also be valid for 35 , provided that the new epistatês were included when both decrees were joined. Drafted in this manner, the enactment clause of 35 would be very concise, but such concision matches the drafting style of this decree, as we saw above, since in the rider of Hestiaios the usual

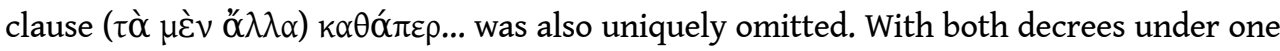
prescript, the phyle Leontis could claim credit for the whole Athena Nike-plan and its execution. A similar sequence of events is recorded in $I G \mathrm{I}^{3} 68$, listing consecutive decisions in the prytany of Kekropis, but in this case the prescripts of the two decrees are 
twice included in full, and the decrees and their riders were finally inscribed on a single stone. ${ }^{66}$

Why were decrees pre-35 and 35 not likewise inscribed together on one stone? I can only explain the present construction by assuming that decree pre-35 was already inscribed and that the Athenians - more precisely, the phyle Leontis - were reluctant to discard this stone, for instance because it was already consecrated to Athena Nike and / or carried a (small) relief, when they had to add the new decree 35. In this situation, it might have made sense to join the original stone with the dowels to a new one, which next was inscribed with 35 .

Some further support of this hypothesis may be found in the drafting of decree 35. It is not only quite lapidary, but the logical coherence of this decree is also difficult to see: the proposal first concerns the creation and selection of a priestess, next doors for the sanctuary with the necessary design and costs. Then it returns to the priestess, namely her perquisites, and next again to the sanctuary, its new temple and a new altar. As Robin Osborne points out, we miss here the arguments of decree $35 .{ }^{67}$ On my hypothesis, pre-35 entailed the main argument, to which decree 35 provided meaningful additions. New sacrifices invited a new priestess to perform them. And with new dêmosios money assigned for the sacrifices that would not all be spent at once, added to the goddess' existing ample treasury, doors to protect the sanctuary were called for. The priestess was to receive a fitting remuneration and in a crescendo the whole plan was topped by an entirely new temple and altar, in line with the Akropolis building program. The inscribed decrees would draw permanent attention to the decisions of the dêmos made in the prytany of Leontis to honour Athena Nike to the benefit of the polis.

The reason for decree $I G \mathrm{I}^{3} 36$ can only be guessed at, but if my hypothesis is valid, some conjectures can be made. Once the dêmosios money was collected (or set aside) for the sacrifices, it belonged to the goddess, but due to its special purpose it probably was not added to her regular treasury. The kolakretai were the obvious body to be in charge of this fund, since their functions included among other things handling (money meant for) sacrifices at polis level. ${ }^{68}$ They provided the money for a comparable provision for Bendis: a priest (ess?) and civic sacrifices for her festival (IG I 136 l. 32-39; 413/2?) plus the stele on which this decision was inscribed. Bendis, too, had her own treasury before and beside this extra dêmosios money, at least since $429 .{ }^{69}$ So I do not think the role of the kolakretai was the new element of this decree. Rather, it was not obvious when the overall remuneration of the priestess of Athena Nike for her sacrifices throughout the year should be paid. Apparently, Kallias proposed to settle this issue in (probably) 424/3. But this decree does not illuminate when the priestess had begun her duties, nor the stage in the completion of the temple.

\section{The tenure of the priestess}

Finally, I turn to the question of the tenure of the priestess. Was hers a life-time or an annual office $?^{70}$ As far as we know, at Athens in the fifth century until decree 35 all polis cults were served by priests and priestesses from the genê, whose office was for life. ${ }^{71}$ This life-long tenure fits a wider Greek pattern, exemplified in the tenure of the priestesses of Hera at Argos, used for dating purposes by Hellanicus of Lesbos, counting 'in the xth year of the priesthood of $y^{\prime} .^{72}$ At Athens, after Perikles' Law all citizens were qualified for priesthood due to their descent from two Athenian parents, and new priesthoods could be 
filled from among the dêmos. ${ }^{73}$ On our extant evidence, the priestess of Athena Nike was the first of this kind. Perhaps this priesthood owed some of its conception to the Pythia at Delphi, who was selected from among all Delphian women, as was well-known at Athens; she too served the god for life. ${ }^{74}$ Annual office of priests became attested at Athens from the fourth century onwards, for instance for the male priesthood of Asklepios, another polis priesthood established in the later fifth century on the democratic model of selection 'from all'. ${ }^{75}$ Some male priesthoods of this type came to be filled by rotation among the phylai, but still of course 'from all'.

But did priesthoods held by women also change to this annual pattern? Annual tenure of a priestess has been inferred from a decree of 283/2 passed by the Assembly to cleanse

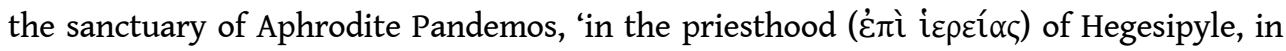
the archonship of Euthios'. ${ }^{76} \mathrm{I}$ am not convinced, however, that this phrasing indicates dating by annual office of this priestess beyond a doubt. The preposition epi with genitive indicates the time of office and with it the authority of the office in which the event took place. When it refers to an annual office, epi in effect indicates the relevant year, but in the case of offices of a different duration, it is questionable if the preposition itself refers to a year. We find epi indicating the time of office of priestesses of Athena Polias, priesthoods that were certainly lifetime offices, held by women belonging to the genos Eteoboutadai. ${ }^{77}$ In the case of the decree on the sanctuary of Aphrodite Pandemos, one could argue that the archonship of Euthios was added to indicate the year of the event, joined to authority of the office of the priestess Hegesipyle. And even if this priesthood was annual in $283 / 2$, this does not mean that it had been so from the beginning.

Instead, I would argue that the tenure of the priestess needs to be understood within the gendered pattern of holding public office in Athens. As Christiane Sourvinou-Inwood observed, male and female citizens were both active in public office, but the terms of office holding were structured along gender lines. ${ }^{78}$ We saw that in the mid-fifth century all priestly offices, belonging to the genê, were lifetime appointments. Women's offices were all cultic offices, primarily as priestesses, and were typically life time appointments. By contrast, annual office was typical of men's offices (archai) in the political context of the polis. The new priesthood was a major change in that now 'all citizen women' were eligible for this office, instead of assigning the new sacrifices to an existing genos or an archon. But casting a female office in the masculine frame of annual office holding would have been incongruous. That in the course of time male priestly offices 'from all' ceased to be lifetime appointments on the model of the genê priesthoods, but were made to fit the pattern of annual rotation on the model of 'political' offices, is an interesting development, but it was not necessarily carried over into women's cultic offices.

\section{Conclusions}

On a re-reading of $I G \mathrm{I}^{3} 35$ and 36, I suggest that the polis Athens at some point after 448 decided to honour Athena Nike with new sacrifices paid by the dêmos, perhaps to induce the goddess to grant her support before campaigns and probably to thank her after victorious battles. In many respects, the new sacrifices fit a wider pattern of dêmotelês festivals honouring the gods and heroes of Attica, especially in commemoration of their help to Athens during the Persian Wars. Once this decision about the sacrifices was made, decree 35 added a radical step by creating a new priestess to perform them, to be selected not from the genê but from all Athenians. Nike's cult, including the money of the dêmos 
for the sacrifices, was to be gloriously housed in a new temple and a fitting new altar for the sacrifice was commissioned.

Listing the relevant decrees with their possible dates and implications we find the following. The plan of the temple commissioned in decree IG $\mathrm{I}^{3} 35$ requires the raising of the bastion, a construction integrated with the southwest wing of the Propylaea. If the plan for this wing was an integral part of the design of the Propylaea, the decree was made probably before 437, when work on the Propylaea began. The presence of a large treasury of Nike in her sanctuary before $433 / 2$, which required some protection by fitting doors to it, further points to a date before 433 , and the more so if extra money collected from the dêmos for the sacrifices was to be stored here. Kallias A brought the treasuries of the Other Gods to the Akropolis, with presumably further protection of all these treasures. In sum, all this evidence weighs heavily towards a date of decree 35 after 448 and before 437 or the mid- 430 s.

Once the decree was enacted and the priestess selected, she could enter her office straightaway. The priestess held her office for life and she was remunerated after each sacrifice by perquisites in kind and for all the sacrifices throughout the year by a payment of 50 drachmas. In $424 / 3$ probably, decree 36 ruled to make the payments due to her in Thargelion. But a date for decree 35 in the early 420 s cannot be ruled out, assuming that the war and the pestilence did not preclude a decision of this kind. If the decree was enacted coherent with the revision of the south wing in the early 420 s, the bastion could have been finished in 425 when the new statue was dedicated and next the trophies were attached. A few years later, the temple was finished.

\section{Appendix}

\begin{tabular}{|c|c|c|}
\hline Decree / account & $\begin{array}{l}\text { possible } \\
\text { date }\end{array}$ & Comment \\
\hline \multirow[t]{3}{*}{$I G \mathrm{I}^{3} 35$} & After 448 & Beginning of Periklean building program \\
\hline & Before 437 & $\begin{array}{l}\text { Beginning of Propylaea construction. Plan for southwest } \\
\text { wing including bastion? }\end{array}$ \\
\hline & $\begin{array}{l}\text { Before } \\
433 / 2\end{array}$ & $\begin{array}{l}\text { Large loans from treasury of Athena Nike show full treasury; } \\
\text { doors to sanctuary advisable. }\end{array}$ \\
\hline$I G \mathrm{I}^{3} 45$ & $?$ & $\begin{array}{l}\text { Protection of Akropolis against intruders by construction } \\
\text { and guards. }\end{array}$ \\
\hline $\begin{array}{l}\text { IG I }{ }^{3} 52 \text { A (Kallias } \\
\text { A) }\end{array}$ & $432 / 1(?)$ & $\begin{array}{l}\text { Payment of money owed to the gods; treasuries of the Other } \\
\text { Gods collected on Akropolis. }\end{array}$ \\
\hline IG II $\mathrm{II}^{3} 444\left(=\mathrm{II}^{2} 403\right)$ & 425 & Bronze statue of Athena Nike; in new sanctuary? \\
\hline$I G I^{3} 36$ & $424 / 3(?)$ & Payment of priestess settled in Thargelion. \\
\hline $\begin{array}{l}\text { IG I }{ }^{3} 52 \text { B ('Kallias' } \\
\text { B) }\end{array}$ & $422 / 1(?)$ & Financial provisions; some reference to the Propylaea. \\
\hline
\end{tabular}




\begin{tabular}{|l|l|l|}
\hline & $\begin{array}{l}\text { Before } 420- \\
18\end{array}$ & Nike temple finished \\
\hline
\end{tabular}

\section{$I G I^{3} 35$}

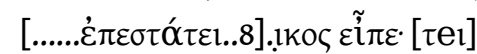

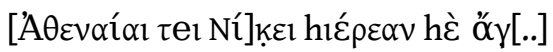

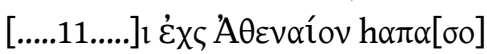

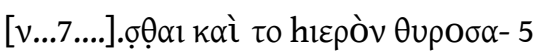

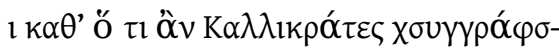

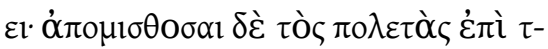

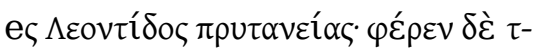

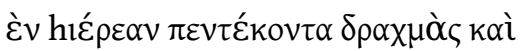

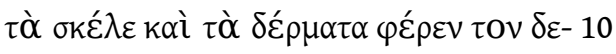

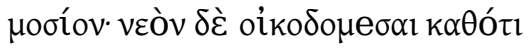

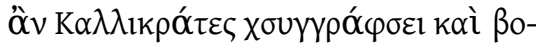

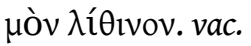

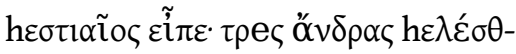

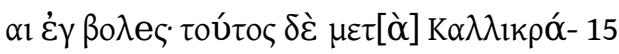

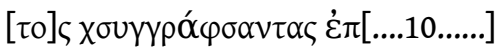

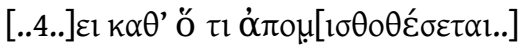

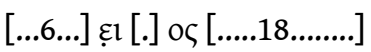

44 


\section{Translation}

[...].ikos proposed: to select (or: establish) as a priestess for Athena Nike whoever will be [allotted] from all Athenian women and to provide the sanctuary with doors in whatever way Kallikrates will specify; and the poletai are to place the contract within the prytany of Leontis; the priestess is to receive fifty drachmai and to receive the backlegs and hides of the dêmosios sacrifices; and that a temple be built in whatever way Kallikrates may specify and a stone (marble) altar. vac.

Hestiaios proposed: that three men be selected from the boulê; and that they will make the specifications with Kallikrates and [.....] in accordance with [the contracts...]

\section{Epigraphical commentary}

7 IG I $\mathrm{I}^{3}$ gives height 0,39 m.; this cannot be right; in this, it follows IG $\mathrm{I}^{2} 24$, which states max. $0,39 \mathrm{~m}$. Neither Tod nor ML give measures. S.V. Tracy (1984) identified the cutter as the cutter of IG $\mathrm{I}^{3} 435$.

Line 1: signs of I and MO were first seen by von Prott at autopsy of the stone (see Syll. ${ }^{3}$, p. 77) and included in Ziehen's edition in LGS. I can only confirm the last two letters: two small vertical dots that could be A but more likely $\mathrm{M}$, and a small circle that could be either $\mathrm{O}$ or $\Theta$. These traces are visible when the stone is lighted from above, not with only the daylight coming from the left on its current position in the New Akropolis Museum. Where Prott saw the I, the stone is now too severely damaged to be legible without additional light. The first line is legible on none of the squeezes, and it seems that both IG and ML relied on von Prott here.

Line 2: (Fig. 5) in the name of the speaker, a small vertical stroke is visible before $\mathrm{K}$ that Meritt read as $Y$, but I seems to me more likely, because the $Y$ of this cutter has a slightly rounded left-bending left stroke, whereas this letter is a straight vertical one. Preceding this letter, W. Dinsmoor (1941), p. 159, n. 337, noted a sloping line, taken to be A. Meritt and $I G$ reading $Y$ restore $[\Gamma \lambda] \alpha u \kappa o \zeta$, so does Guarducci, who follows Meritt and Wade-Gery (1963) throughout her text. ML, accepting the A and next reading I, suggest a name

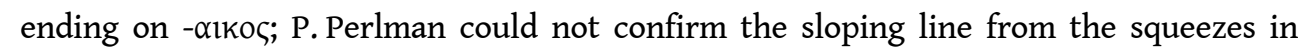
Texas, but instead she saw traces of a circular letter $(\mathrm{O}$ ? $\Theta$ ?) and suggested names ending

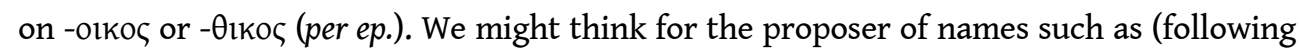

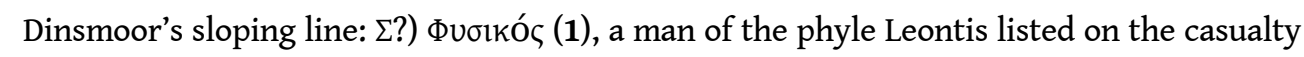
list of ca. 411 (IG I ${ }^{3}$ 1190.152), or (following Perlman's O) NÉoıkoৎ (1), a man whose son Theodotos was on the board of the Delian Amphiktyones in 410/9 (IG I $\mathrm{I}^{3}$ 1460.4). These possibilities suggest the type of name but cannot be taken to establish the identity of the

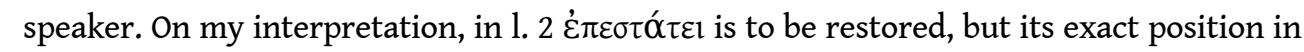
the line is impossible to tell. On the hypothesis of a short name of the proposer, such as the ones suggested above of seven letters, the epistates could have a name of nine letters. 


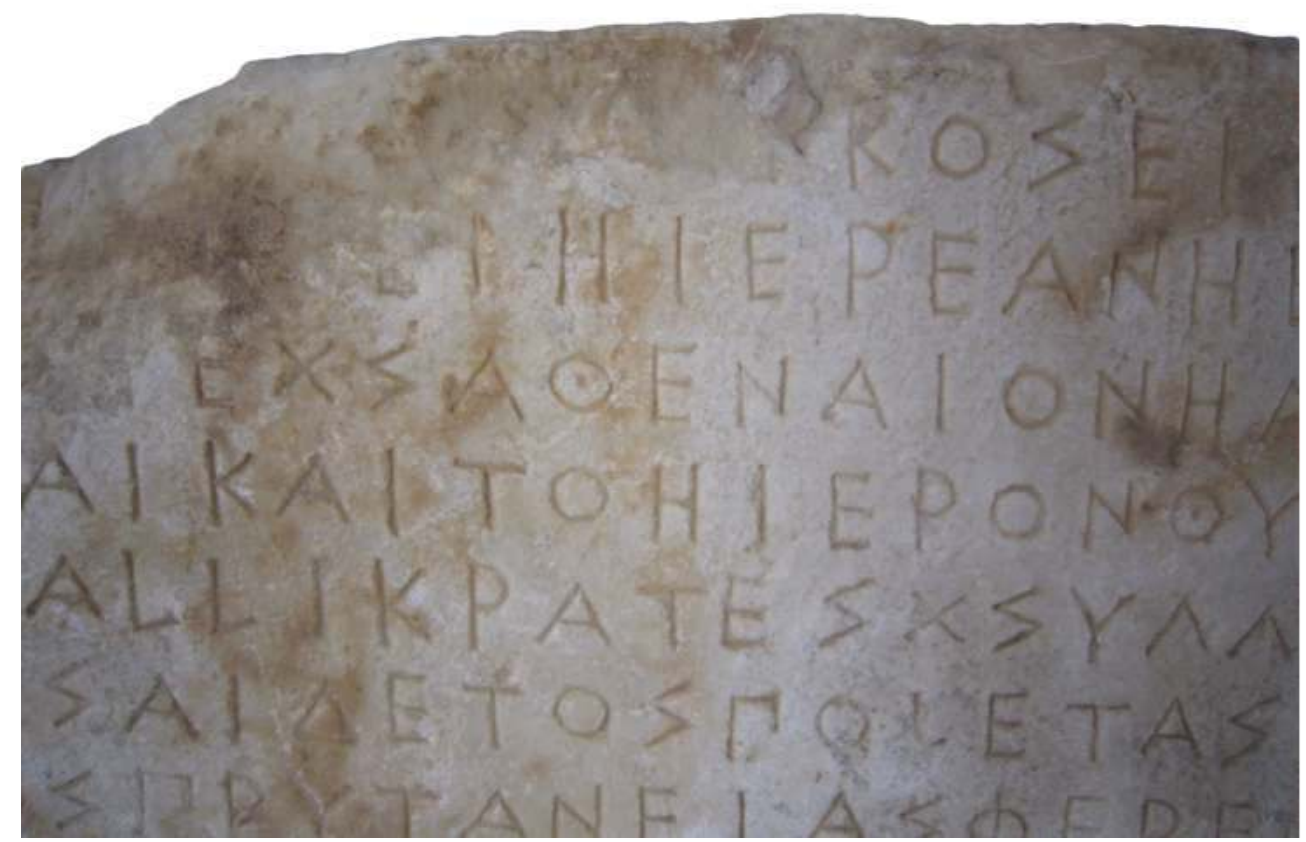

Figure 5

Photo: Josine Blok, by courtesy of the New Akropolis Museum Raubitschek (1964); Mattingly (1996); Mattingly (2000).

\section{Text}

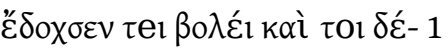

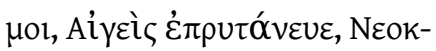




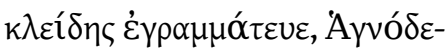

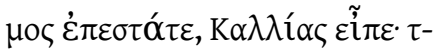

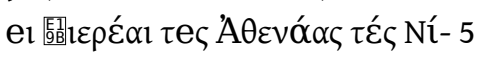

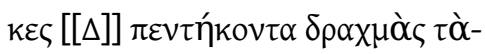

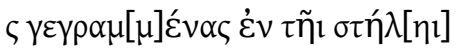

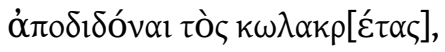

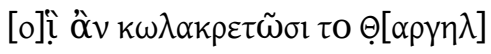

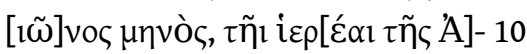

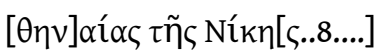

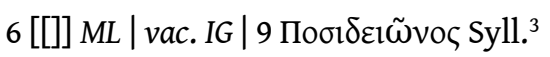

\section{Translation}

The council and assembly decided, Aigeis held the prytany, Neokleides was secretary, Hagnodemos presided, Kallias proposed: for the priestess of Athena Nike the kolakretai, who will be in office in the month Thargelion, are to pay the fifty drachmas that are written on the stele to the priestess of Athena Nike...

\section{Epigraphical commentary}

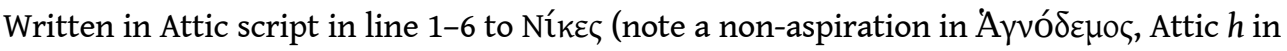

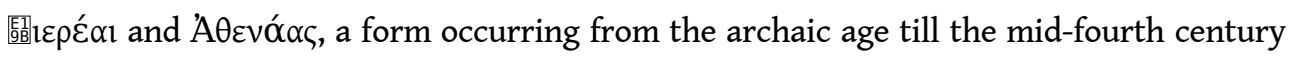
[Threatte (1980), p. 271-274]), after the erasure in line 6 in Ionic script by a different hand with slightly smaller script and a somewhat uneven stoichedon.

In line 6, IG takes the erasure to be a vacat and $M L$ an erasure of the numeral 50; ML seems to follow Ziehen here, who interpreted the erasure indicated in von Prott's autograph to be an erased numeral (LGS II, 47). These interpretations of the erasure, which rely on squeezes, are impossible at autopsy of the stone. A sloping line from left to right is clearly visible on the stone (Fig. 6) and confirmed by the squeezes in Texas, which cannot be attic $\Pi$ and is too large for the numeral. It could be the beginning of the Attic gamma $\Lambda, A$ or $\Delta$. Next, this sloping line was erased and someone else continued the inscription, beginning with 'fifty drachmas'. I would argue that the first cutter began $\Delta$ for drachmas, forgetting the numeral, and that after this error he was replaced by someone else, who carried on with the correct words and writing the amount in full, not as a numeral, just as in the text of 35 to which decree 36 explicitly refers here. The use of Ionic script by this second cutter, despite the Attic in which decree 36 began, for the same decree strongly suggests that the choice for Attic or Ionic script was not (only) up to the grammateus, but could equally be up to the cutter. This conclusion must be taken into account in the debate about the use of Ionic script in inscriptions in these years, on which see further Matthaiou (2009). 


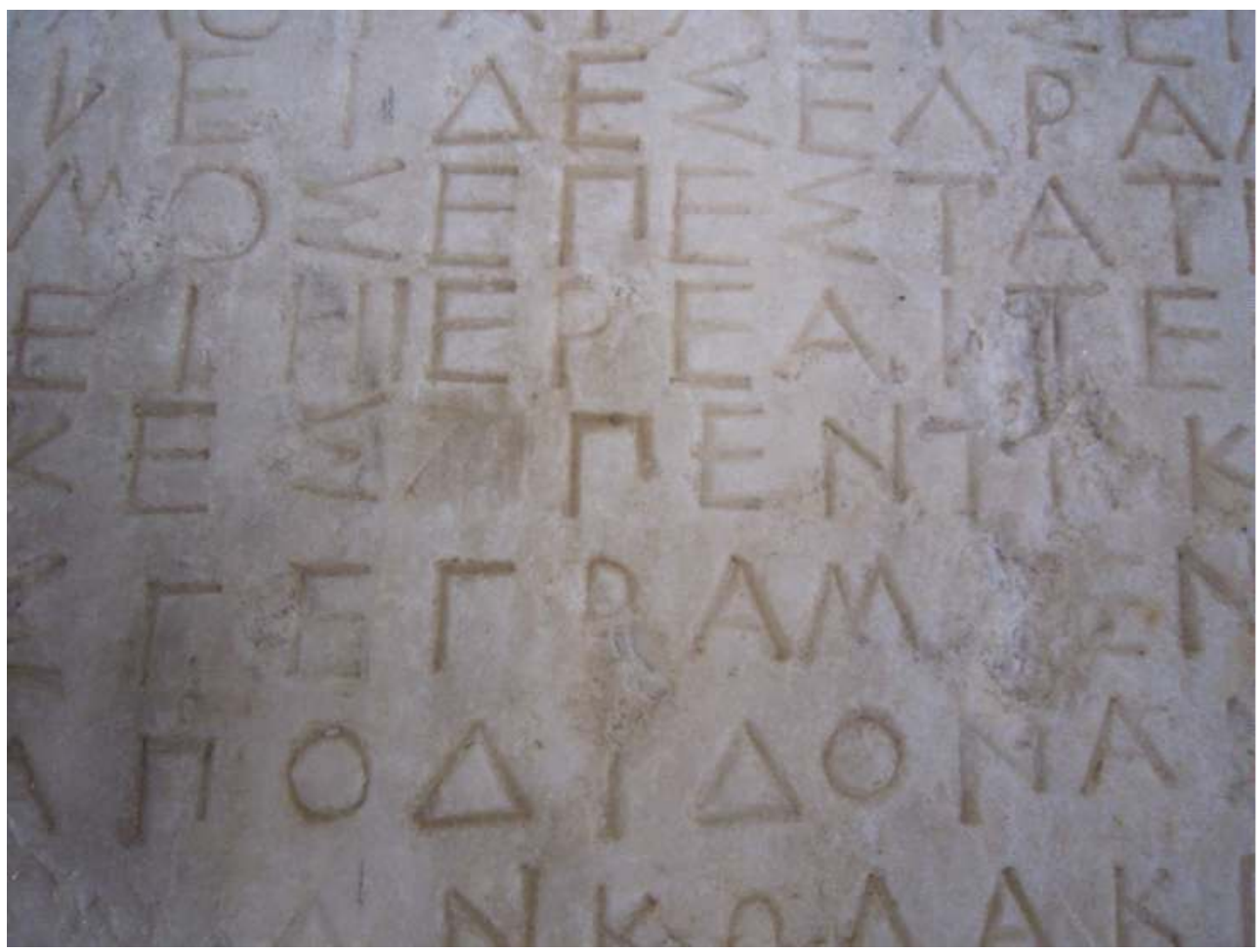

Figure 6

Photo: Josine Blok, by courtesy of the New Akropolis Museum

59 In line 9, the $\Theta$ seen by von Prott cannot confidently be confirmed from the stone, but on one squeeze in Texas the upper curve is visible and the number of letters is consistent

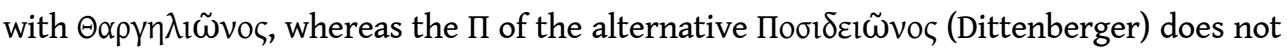
match either the stone or the squeeze.

\section{NOTES}

*. The core of this article was presented at the conference 'Reading' Greek Religion (Archaic and Classical): Literary, Historical and Artistic Perspectives' convened in memory of Christiane SourvinouInwood by Athena Kavoulaki at Rethymnon, Crete, 22-24 Sept. 2012; I am most grateful to Athena Kavoulaki for inviting me to this conference and for the response of the participants to this paper.

1. For both decrees, I refer to the texts, made on autopsy and compared with the reports on the squeezes, which are included at the end of this article. The stone with decrees IG I ${ }^{3} 35$ and 36 is now on display in the New Akropolis Museum, Athens, and I am most grateful to the Directors of the Museum for allowing me to study the stone on its pedestal and for their kind permission to take and publish photographs. Dr. Paula Perlman (Univ. of Austin, Texas) kindly checked for me the squeezes of both inscriptions once in the possession of B.D. Meritt. For this article, I am greatly obliged to Robin Osborne, P.J. Rhodes, an anonymous referee for Kernos and above all 
Stephen Lambert for comments on previous drafts; of course, responsibility for the present text rests solely with me.

2. For the debate on the three-bar-sigma and its consequences, RHODES (2008), who retains a date early in the 440s for IG $\mathrm{I}^{3} 35$. PAPAZARKADAS (2009) shows that due to the revision of the 'old' dates of many decrees with three-bar sigma and tailed-rho, the interdependence of these decrees causes a domino-effect of downdating, which often (but not always) tends to confirm dates H.B. MATTINGLY defended over the years, as collected in MATTINGLY (1996).

3. SOURVINOU-INWOOD (2000); SOURVINOU-INWOOD (1991).

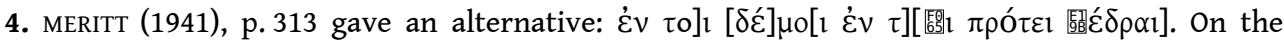
common but not invariable use of the prescript, RHODES (1972), p. 64, 71 n. 2; HENRY (1977), p. 1314 classifies the heading of IG $\mathrm{I}^{3} 35$ as 'problematic'.

5. For such statements on (possibly contemporary) decrees: IG I $I^{3} 32.32-4 ; 23.9-14 ; 24.9-14 ; 43.20-$ 1 (?); 46.21-3; on 35, it could have been included on the lower, now missing part of the stone.

6. The epitaph of Myrrhine, the first woman selected by lot to be priestess of Athena Nike, is an epigram ( $I G \mathrm{I}^{3}$ 1330) of 16 lines on a marble stele; for text and monument, RAHN (1986) and LOUGOVAYA-AST (2006). Comparison with funerary monuments and epigrams favours a date ca. 420-400, adding the issue of the priestess' age at the moment she entered her office to the discussion about the type of her tenure and the date of the decrees. D. LEWIS (1955), following a suggestion of I. PAPADEMETRIOU, supposed that Myrrhine was perhaps reflected in the woman of the same name in Ar. Lysistrata of 411, and that the protagonist could be identified with Lysimache, the contemporary priestess of Athena Polias. LEWIS' suggestion, attractive though it is, raises many questions. Why was the name of Lysimache changed in Lysistrate, although the real name would also have fitted the plot (as Lewis notes; Ar., Lys., 554), whereas Myrrhine's was left in the original form? Myrrhine was, moreover, a very common feminine name; can we be sure it was firmly associated with the priestess? A strong argument in favour of the identity is Ar. Lys. 207-208, where the woman Myrrhine is told she cannot be the first to take the oath unless she draws the first lot (CONNELLY [2007], p. 63). Lysistrate was the name of a mid-fifth century priestess of Demeter (dedicating IG $\mathrm{I}^{3}$ 953), in 415 the priestess was Theano (Plut., Alk., 22, 33); see BLOK and LAMBERT (2009), p. 119, Philleidai no. 1 and 2. If Aristophanes indeed made a pun on the names of two or three well-known priestesses, he did so in a way so loose that we must be wary to use this as evidence supporting other arguments.

7. DINSMOOR (1923).

8. MERITT (1941), p. 311-315; Stephen LAMBERTper.ep.

9. MERITT (1941), p. 313-314.

10. MERITT and WADE-GERY (1963), p. 109-310.

11. $M L$, p. $110-111$.

12. More or less contemporary decrees with riders are $I G \mathrm{I}^{3} 32,1.6-7$ and $35 ; I^{3} \mathrm{I}^{3} 40,1.40$ and 70; IG I $\mathrm{I}^{3} 46$, 1. 36-40; IG I $\mathrm{I}^{3} 49$, 1. 13; IG I ${ }^{3} 56,1$. 9-10; IG I ${ }^{3}$ 65, 1. 8-9. In all these cases, riders are included in the final inscribed text, without repeating the enactment formula. All riders begin with ( $\tau \dot{\alpha}$

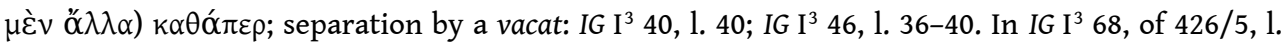
30-33 the whole enactment clause is repeated, with a different epistates on another day of the same prytany (but with the same man speaking; on this text, see also below). Only $I G \mathrm{I}^{3} 35,1.15$ has no rider-formula, but it has a clear vacat before the rider. Whether the omission of the rider formula is due to the secretary or the cutter we cannot know. MERITT (1941), p. 314, still taking the beginning of 35 to be a rider and restoring in 1.2 the name of the proposer as [Gla]ukos, supposed that the rider was punctuated by a vacat space of one stoichos before the name, fitting a restoration with an epistates. However, the restoration 'Glaukos' is highly unlikely (see Appendix). On the cutter, S.V. TRACY (1984) showed that the man who cut IG $\mathrm{I}^{3} 35$ also cut IG $\mathrm{I}^{3}$ 435, known as the Promachos-accounts until recently STROUD (2006) cast fundamental doubts on 
this identity of the fragments, which may not even all belong to the same inscription and are anyway too damaged to allow the drafting of the text to be compared with IG $\mathrm{I}^{3} 35$.

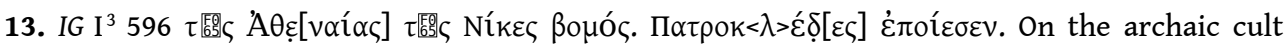
statue, MARK (1993), p. 20-30, 125 (date 600-560 BCE), but see also SHEAR (1999), p. 88 n. 11, with ref. to D. GIRAUD (1994), p. 32-34 (non vidi).

14. ALESHIRE (1994), LAMBERT (2010), p. 144-147.

15. On these figurines, MARK (1993), p. 22, 52-53, 66-67 with further lit.

16. IG $\mathrm{I}^{3} 506$ and 775; on some other dedications to Athena, $\pi \alpha_{1} \delta \grave{\imath} \Delta \mathrm{lò} \zeta \mu \varepsilon \gamma \alpha$ ó $\lambda_{0}$ is added. IG II ${ }^{2}$ 4329; 4338; IG I ${ }^{2} 561$ are fourth c. dedications to Athena Ergane. Many dedications to Athena are first fruits (aparchai).

17. PARKER (1996), p. 90, n. 95.

18. For Athena Nike as a goddess of victory in war, PARKER (1996), p. 90, PARKER (2005), p. 398-399.

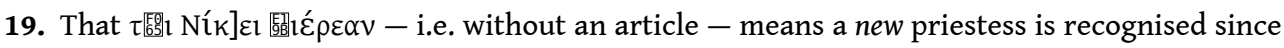
MERITT (1941), p. 310-311.

20. MERITT (1941), p. 310-311; tentatively LAMBERT (2010), p. 155.

21. LAMBERT (2010), p. 155, 158-60.

22. Her rich treasury was accounted for by the logistai of debts of the polis to the gods (IG $\mathrm{I}^{3}$ 369.51; ML 72) in 423/2; they include substantial sums belonging to Nike that had been on loan for eleven years. The treasury of Nike is accounted for separately from the treasuries of Athena and of the Other Gods.

23. For the date of the altar, SHEAR (1999), p. 122-124; this date blocks the way for MARK'S argument (1993, p.36-122, 128-141) that this limestone altar belonged to a temporary construction made by Kallikrates according to the decree IG $\mathrm{I}^{3} 35$.

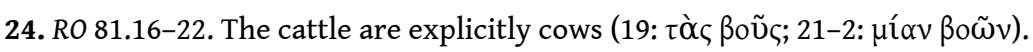

25. $R O$, comm. p. 401-402.

26. Ath.Pol. 58, listing the duties of the Polemarchos including sacrifices to Artemis Agrotera, Enyalios and Harmodios and Aristogeiton, does not mention such a sacrifice to Athena Nike. Ath.Pol. describes the situation in the late fourth century and neither its historical nor its contemporary account is exhaustive. Silence on this matter therefore neither proves nor disproves the conjecture that before the mid-fifth century the Polemarchos was in charge of the sacrifices for Nike.

27. JAMESON (1994) p. 313-317 on the sacrifice of the male cattle before battle depicted on the parapet; on the program, see also HURWIT (1999), p. 213-215; for the date of the parapet in 415 or even close to 410, p. 214.

28. For the statue, $I G \mathrm{II}^{3} 444\left(=\mathrm{II}^{2} 403\right)$, the spoils of campaigns in the Archidamian War: Thuc., III, 85, 106-112, 114; IV, 49; for the identity of the statue, MATTINGLY (2000), p. 605, LAMBERT (2012), p. 66-68. In the earlier years of the Archidamian war, before the completion of the temple, Athens set up war trophies in various places, schultz (2001), p. 38-39 and n. 128.

29. Schultz (2001), p. 40, with bibl. in n. 136.

30. At this point, the debate also involves Kallikrates as architect of parts of the Akropolisprogram. HOEPFNER (1997) argues that the conjunction of the Nike-temple with the Propylaea must have been designed in its entirety by Kallikrates, but HURWIT (1999), p. 209-211 more cautiously holds that the Nike temple structurally belongs to the Periklean conception of the Akropolis and that the architect of the temple must have been someone who took Mnesikles' plans into account. MARK (1993) argues for a stage between the raising of the bastion with a temporary sanctuary and the final Ionian Nike temple, but see above, n. 23.

31. MILES (1980), p. 323-324: 'The raising and sheathing of the bastion directly involved the laying of the foundations for the Temple of Athena Nike. This is indicated by the northwest corner of the bastion, where the foundations are bonded into the sheathing of ashlar masonry, and by the 
fact that the courses of the western and northern foundations of the temple follow the courses of the bastion wall, level by level.' For the coherence of technical and architectural aspects of the Propylaea and Nike-temple, see also MARK (1993), p. 79-82; SHEAR (1999), p. 124-125. DINSMOOR (1923) and SHEAR (1999), p. 124 even argue that a stone lintel in the corner of the southwest wing, between the Propylaea and the temple, had held the Athena Nike-decree. Attractive though this idea may be, it is impossible to ascertain that this particular stone and no other stood there.

32. See also $M L 71$, comm.

33. MILES (1980), cf. CAMP (2001), p. 105-6; Paus., I, 19, 6. We must note, however, that the absolute date assigned to the Ilissos-temple depends on the dating of the Nike temple, which in turn depends on the 'Kallias'-decrees, see below.

34. MARK (1993), p. 136, comparing the friezes with the relief on the Bridge Decree (IG I $\left.{ }^{3} 79,422 / 1\right)$ and other decree-reliefs, IG I ${ }^{3} 86$ of $417 / 6$ and IG I ${ }^{3} 101$ of 410/9.

35. MARK (1993), p. 86, and n. 86, where he contests MILES (1980), p. 323 that the marble working chips under the pavement of the Nike sanctuary stem from the Propylaea-project. Likewise for the Nike-temple schultz (2001), p. 1 with n. 1: 'completion in the mid to late 420s', with further bibl.

36. HURWIT (1999), p. 209-211, on TOMLINSON (1990).

37. The first accounts of the construction of the Propylaea (IG I $\left.{ }^{3} 462-466\right)$ run from 437 to 432 (?) but the building was not finished by then.

38. In a nutshell, the conventional view developed when WADE-GERY (1931) restored the now missing prescript of $B$ as the same as that of A, proposed by the same man, with the same epistatês Eupeithes and passed on the same day. The Panathenaeic year of B (1.28), as well as the absence of recorded repayments to the Other Gods between 433 and $423 / 2$ that recur in B, together assigned B to $434 / 3,422 / 1$ or $418 / 7$. Although first proposing a date in the 420 s, WADE-GERY (1947) revised his view on the date of $B$, assigning both sides to 434 . The texts with restorations were published in ATL (MERITT-WADE-GERY-MCGREGOR [1939-53] I, 1939), D 1 and 2 (p. 160-1), where in B

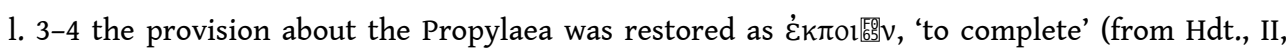
125), allegedly calling for a rapid termination of the work. Fundamental criticism on the cutters, dates and contexts of the decrees came from MATTINGLY (1964) and PRITCHETT (1971) casting doubts on the restored prescript of B due to a lack of evidence for either epistatês or proposer. Nonetheless, the texts and datings of the Kallias decrees defended by MERITT and WADE-GERY were widely accepted, among others by BUNDGAARD (1976), p. 125-133, proposing that the early work on the Propylaea had been hastily completed in 434 for financial considerations due to the immanent war. With BUNDGAARD's work, this view of the construction history of Propylaea and Nike-temple also became established in the archaeological literature; see e.g. HOLTZMANN (2003), p. 156.

39. KALLET-MARX (1989), reinforcing PRITCHETT'S views, saw traces on the stone incompatible with the restoration of the name Eupeithes as epistatês (confirmed by M.H. CHAMBERS, see SAMONS [2000], p. 128, n. 83). The separation of B from A opened a date for Kallias A in non-Panathenaeic years. KALLET also cogently argued on grounds of the financial arrangements for a temporal disjunction of Kallias A and B and for a date in 431/0 for A and 418/7 for B. SAMONs (2000), p. 215229 following on KALLET'S views argues that in 433/2 expenditures to do with the Kerkyraean expedition (IG $\mathrm{I}^{3} 364$ ) and the large debts to the gods accounted in the Epistatai decree (IG $\mathrm{I}^{3} 32$, convincingly dated by CAVANAUGH [1996], p. 19-27 to just after 433/2), both suggest a date for Kallias A in that same year, which now shows a consistent concern about sacred monies on the eve of the war. While 432 was the moment of the decision of A, its inscription in stone took place at a later date. Kallias B was decided in $422 / 1$ and when B was inscribed, A was inscribed as well as the reverse of B, so SAMONS. RHODES (forth.) reviews the debate, preferring, however, the older date for both decrees. 
40. MATTINGly (1996), p. 470-471; WADE-GERY (1958), for the date also following MERITT and DAVIDSON (1935). Discussion of the date of $I G \mathrm{I}^{3} 36$, which is plausible but not absolutely certain, is beyond the scope of this article.

41. MARK (1993), p. 136; SCHULTZ (2001), p. 1 and n. 2.

42. MATTingly (1996), p. 461-471: IG I3 35 in ca. 430; MATTINGLY (2000), p. 605-606: in 425, in the same year and prytany as IG $\mathrm{I}^{3} 71$. For the 'further decisions' on the temple, he refers to $I G \mathrm{I}^{3} 84$ A.17, but this must be an error.

43. Often this view is implied, for instance schultz (2001), p. 1: IG $\mathrm{I}^{3} 36$ shows that the cult of Athena Nike was fully active' - but the cult had been 'active' for a long time.

44. '(Annual) salary': ML p. 108, MATTINGly (2000), p. 606, schultz (2001), p. 1, LUPU (2003), p. 47, CONNELLy (2007), p. 200, TSOUKALA (2009), p. 9, BLOK (2010), p. 82, LAMBERT (2010), p. 154 etc.

45. A thês (in epic) sold his labour for a year to an employer for a fixed recompense (food, clothing, some money); Hom., Il. XXI, 445: the gods Apollo and Poseidon served Laomedon 'like thêtes for a year at a fixed misthos'.

46. For a survey of misthoi and wages at Athens, LOOMIS (1998), p. 76-87 for perquisites of priests and other religious personnel; for the priestess of Athena Nike, LoomIs aptly avoids 'salary', calling it 'general compensation for the year' (76 and 78 n. 7). For priestesses we also find in Athens apometra, which seem to be payments in money; see e.g. IG $\mathrm{I}^{3} 255 \mathrm{~B} 1.10$ where a priestess seems to receive $10 \mathrm{dr}$. apometra plus hides of dêmosios sacrifices. The anonymous referee of Kernos points to similarities between the arrangement of decree 35 for the priestess and the 'priestly contract', an epigraphic genre well attested in the Hellenistic era in various cities, although not in the classical age in Athens. The absence of such contracts in Athens makes assigning a similar character to 35 not highly attractive, but the issue is worth exploring.

47. LE GUEN-POLLET (1991); EKROTH (2008), TSOUKALA (2009).

48. Mysteries: $I G \mathrm{I}^{3}$ 368.161-164; tribal priests, polis calendar SEG 52.48: fr. 3A, 1. 52.

49. SEG 52.48: Athena Polias, fr. 6A 1. 3; Priestess of Demeter fr. 3A 1. 76.

50. A new priestess: MERITT (1941), p. 310-311 (see above, n. 19).

51. PIRENNE-DELFORGE (2005). For a probable parallel of this use of $\tau$ 嶇 $v \delta \varepsilon \mu \sigma$ óov, $I_{G} \mathrm{I}^{3} 255 \mathrm{~B}, 1.17$ and 21 (ca. 430?).

52. Examples abound: inauguration of the Theseia, of the cult of Asklepios, of some of the eponymous heroes. See PARKER (1996), p. 102-187; LAMBERT (2010).

53. MARK (1993), p. 75 and n. 36.

54. MIKALSON (1975), p.50: Plut., Mor., 349e in a passage recounting the polis festivals commemorating the Persian wars and other victories of the Athenians; 862a on Herodotus' account of these events; Xen., Anab. III, 2, 12; cf. Ar., Eq., 660-662; Lys., 1248-1265. Parker (2005), p. 462. Erroneously Ael., VH II, 25: Thargelion 6 and 300 goats. Day 6 was sacred to Artemis (6 Thargelion was Artemis' birthday: DL, II, 44; Mikalson [1975], p. 18) and 6 Boedromion was probably not the day of the battle of Marathon itself (which happened sometime in Metageitnion?) but rather of the commemorative polis festival close to it.

55. Ath.Pol., 58, 1: polemarchos. First demothoinia: PARKER (1996), p. 153; Suda, s.v. $\eta \mu$ ó $\theta$ o I va

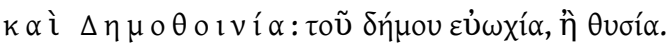

56. PARKER (1996), p. 153-154 and 168-170, 187, for the cultic innovations due to the Persian wars; on the role of the Phytalidai, BLoK (2009a), p. 265; LAMBERT (2010), p. 149 and n. 41.

57. Fragments of sacrifices in Thargelion are preserved on the sacrificial calendar (SEG LII $48 \mathrm{~A}$ fr. 3, 1-15) but according to editor S.D. LAMBERT (2002), they belong to a biennial sequence. The new fragment SEG LII $48 \mathrm{fr} .5$ also contains sacrifices perhaps belonging to Thargelion (GAWLINSKI [2007], p. 46-7) but too much of this is insecure. Moreover, no reference to a sacrifice to Athena Nike is extant on these fragments. 
58. I hope that the difference between this arrangement and a salary over the year is clear; the 50 drachmas would not, for instance, cover her other duties, such as tending the temple, and they certainly were not meant to pay for the sacrificial animals.

59. MARK (1993), p. 135 also connects the payment to the priestess of Athena Nike in Thargelion to Spring and warfare, but supposes that the decree meant to dissociate the festival calendar of Nike from that of Athena Polias, a speculation for which there is neither evidence nor reason.

60. Thargelion is close to the ninth prytany, when at least in the fourth century the rents from sacred leases were received. PAPAZARKADAs (2011), passim and esp. 191-195 shows clearly the connection between incoming rents from sacred properties and meeting the cultic obligations of the dêmos. The sacrifices for Nike, however, were dêmosios, i.e. paid by the dêmos, not by the goddess herself.

61. JAMESON (1994), p. 317; on the particular quality of sphage as ritual, also PARKER (2011), p. 155165.

62. VAN WEES (2004), p. 121

63. JAMESON (1994), p. 318.

64. The identity of the Ilissos-temple as that of Artemis Agrotera (Paus., I, 19, 6) is not epigraphically attested, but highly likely. On this temple and its connection to the Nike-temple and of both to the Persian wars, PARKER (1996), p. 153.

65. For the rubric 'unspecified day', LAMBERT (2002), p. 356-357 and n. 22; Hesych., s.v. $\dot{\eta} \tau \eta v \cdot \tau \eta े v$

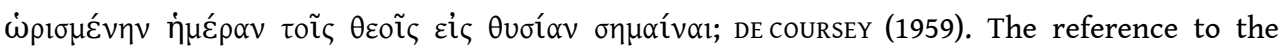
sacrifice is SEG 52, 48 F1A 23-5. After 'for Athena' the stone shows a vacat, suggesting no epithet

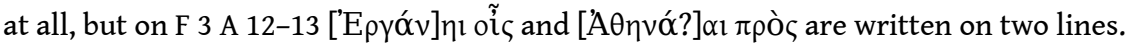

66. IG $\mathrm{I}^{3} 68$ (dated in IG to 426/5) concerns measures to collect the arrear payments of the phoros to Athens. The two decrees (beginning 1.3 and 1. 30) with their riders both belonged to the prytany of Kekropis, and apparently were inscribed together at the very end of the last assembly meeting of this term. The final text of both is drafted in a far more elaborate style than $I G \mathrm{I}^{3} 35$, and without archon years but with otherwise complete prescripts. It matches the pattern of the mid-420s, whereas on these grounds IG $\mathrm{I}^{3} 35$ makes the impression of an earlier date.

67. OSBORNE (2010), p. 67.

68. For the varied financial duties of the kolakretai (paying for stelai, for meals in the prytaneion, etc.) $I G I^{3} 7,11,23,71,73,75$ etc. and sAmONs (2000), p. 57-59, with further bibl.

69. IG $\mathrm{I}^{3} 383$, 1. 143; 429/8, account of the tamiai of the Other Gods; IG $\mathrm{I}^{3} 369,1.68$ (426/5), account of the logistai.

70. For the problem PARKER (1996), p. 126-127, n. 20; LAMBERT (2010), p. 155-156. LOUGOVAYA-AST (2006)'s argument for life tenure on the now contestable early date of decree 35 combined with MARK'S two step construction of the temple taken to be reflected in the wording of the epigram for Myrrhine, is not convincing.

71. BLOK (2009); LAMBERT (2010).

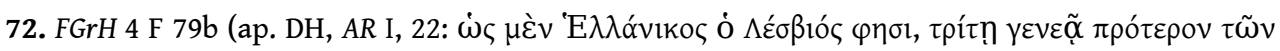

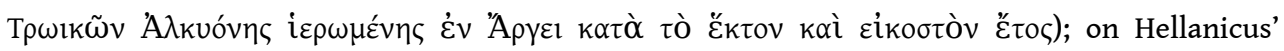
Hiereiai, Möller (2001). Cf. Thuc., IV, 133: in 423, the priestess Chrysis by accident set fire to the temple of Hera; when this happened, she had been in office the eight and a half years of the war, in total for over 56 years. Apparently, annual counting took place within the life tenure of the priestess.

73. BLOK (2009b); LAMBERT (2010), p. 153-161 shows that after Perikles' Law priesthoods for new polis cults were all established on this model of selection from all.

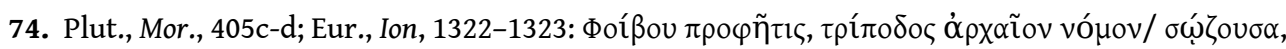

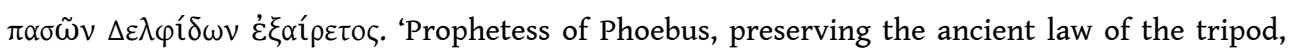

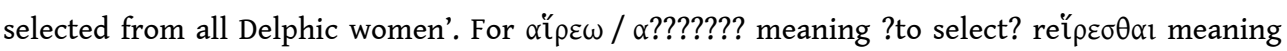


'to select' regardless of the means used, ABEL (1983), p. 18-19. For life: Aesch., Eum., 38; FD III 1: 553, Roman era; Diod. Sic., XVI, 26, 6; Plut., Mor., 405c-d, implies that selection was unpredictable, i.e. by lot.

75. PARKER (1996), p. 126-127; LAMBERT (2010), p. 156-157. Male priesthoods of this kind, notably that of Asklepios in the fourth century and later, were filled by rotation among the phylai. For these developments, LAMBERT (2010), p. 155-161.

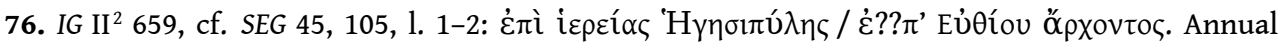
tenure: PARKER (2005), p. 461; according to LAMBERT (2010), p. 158 the reference to priestly office might indicate annual office when it is juxtaposed with epi + archon, e.g. with the annual

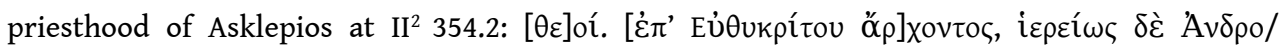

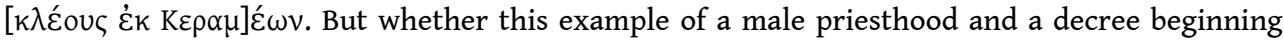
with the archon, followed by the priest, is also valid for the case of the priestess Hegesipyle, where the decree begins with the priestess followed by the archon, begs the question.

77. For instance IG II 2173 (Megiste); 3470 (Penteteris), 3472 (Theodote), 3477 (Habryllis).

78. SOURVINOU-INWOOD (1995). This pattern concerns not only priest (esse)s, but also other cult personnel; some female cult personnel is known to have served for many years, GEORGOUDI (2005); for Syeris, the old diakonos of priestess Lysimache (IG II $\left.{ }^{2} 3464\right)$, KEESLING (2012).

\section{ABSTRACTS}

This article proposes that decree IG I ${ }^{3} 35$ appointing a priestess for Athena Nike and commissioning a new temple and altar followed on a preceding decree inaugurating dêmotelês sacrifices for the goddess, to be made after victorious battles. This decree 'pre-35' was inscribed on the stone that once topped the present, extant stele. The priestess could enter her duties once the decision was made; she did not need the finished temple to do so. IG $\mathrm{I}^{3} 36$ fixed a regular moment for her to be paid for performing the sacrifices throughout the year. A lifetime tenure of the priestess is more likely than one on an annual basis. A date of decree IG $\mathrm{I}^{3} 35$ after 448 and before 437 or the mid- 430s is the most plausible, but the early 420 s cannot be ruled out.

Le décret IG $\mathrm{I}^{3} 35$ met en place une prêtresse pour Athéna Nikè et programme la construction d'un nouveau temple et d'un autel. L'article propose qu'il fasse suite à un décret antérieur inaugurant des sacrifices dêmotelês pour la déesse, accomplis après des victoires militaires. Ce décret « pré-35 » était inscrit sur la pierre qui surmontait la stèle conservée. La prêtresse pouvait entrer en charge dès que la décision avait été prise : elle ne devait pas attendre, pour ce faire, que le temple soit achevé. IG $\mathrm{I}^{3} 36$ fixait la périodicité du paiement qui lui était réservé pour l'accomplissement des sacrifices tout au long de l'année. Un engagement viager de la prêtresse est plus vraisemblable qu'une charge annuelle. La date la plus plausible pour le décret $I G \mathrm{I}^{3} 35$ se situe après 448 et avant 437, ou au milieu des années 430 . Toutefois, le début des années 420 ne peut être exclu. 
AUTHOR

JOSINE BLOK

j.h.blok@uu.nl 